\title{
Reform needs and options in the EU system of own resources
}

\author{
Alexander Hudetz ${ }^{1}$ - Ann Mumford ${ }^{2}$ Danuse Nerudová ${ }^{3}$. \\ Margit Schratzenstaller ${ }^{1}$
}

Published online: 17 October 2017

(C) Springer Science+Business Media, LLC 2017

The current EU system of own resources, which primarily rests on contributions from EU Member States (see for a detailed description Schratzenstaller et al. 2016), certainly has its merits (Núñez Ferrer 2008; Begg 2011; HLGOR 2016). It provides steady, predictable and reliable revenues to finance EU expenditures and guarantees a balanced budget. It also establishes (at least ex ante, i.e. before the application of the various correction mechanisms) a "fair" distribution of the financial burden across Member States. Additionally, national contributions respect the subsidiarity principle by leaving the decision on the distribution of the financial burden among individual taxpayers to Member States (Lipatov and Weichenrieder 2016).

Nonetheless, the current financing system has been attracting a variety of criticisms over a number of decades (Schratzenstaller et al. 2017). An important issue concerns the increasing dominance of direct contributions out of Member States' national budgets into the EU budget, which is continuously curtailing the EU's financial autonomy (European Commission 2011; Iozzo et al. 2008) and furthers a juste retour-logic with all the negative impacts associated with it (Richter 2008). Also the opaque own resources system, which is preventing EU citizens from

Margit Schratzenstaller

Margit.Schratzenstaller@wifo.ac.at

Alexander Hudetz

Alexander.Hudetz@wifo.ac.at

Ann Mumford

Ann.Mumford@kcl.ac.uk

Danuse Nerudová

d.nerudova@seznam.cz

1 Austrian Institute of Economic Research, Arsenal Objekt 20, 1030 Vienna, Austria

2 The Dickson Poon School of Law, King's College London, Strand, London WC2R 2LS, UK

3 Faculty of Business and Economics, Mendel University in Brno, Zemedelska 1, 61300 Brno,

Czech Republic 
assessing their individual and respective country's contributions to the EU budget and the connection between EU revenues and expenditures (Schratzenstaller 2013; Fuest et al. 2015), is seen as problematic. In addition, the application of various correction mechanisms leads to an "unfair" distribution of the financial burden across Member States. Finally, the own resources system neither reflects nor directly supports core EU policies (Schratzenstaller 2013; European Commission 2011, 2017; HLGOR 2016; Schratzenstaller et al. 2017) such as sustainable growth and development.

This lack of support for EU policies, which has been repeatedly stated by the European Commission (e.g. European Commission 2011, 2017) and the European Parliament (e.g. European Parliament 2017), is not only caused by the concrete design of the individual own resources themselves, which at the moment have no direct allocative, distributive or steering effects. It is also due to the perception that the bulk of the current own resources remain pure national contributions. Such a perception induces Member States to measure the benefits derived from the EU budget in terms of net financial contributions, i.e. as a balance of national contributions and transfers received from the EU budget. Financing the EU budget primarily by national contributions furthers such a juste retour-position by MS (Iozzo et al. 2008), demanding the maximisation of net benefits or at least the minimisation of net contributions from their respective country's position instead of the maximisation of an added value from an overall EU perspective. The dispute between "net contributors" and "net beneficiaries" also goes along with increasing tensions between Member States regarding the size and structure of the EU budget (inter alia in the form of the so-called "net contributor debate", see also HLGOR 2016) and exerts downward pressure on the EU's budget volume (Haug et al. 2011). This has manifested itself in the most recent two Multiannual Financial Frameworks, each one lower in volume than the preceding one. Thus, the current structure of the EU system of own resources can be seen as an obstacle to further European integration as well as an obstacle to foster policies necessary for a sustainable economy and generating EU added value (European Commission 2011).

Can tax-based own resources represent a sustainability-oriented option for financing the EU budget in the future? And if yes, which taxes would offer themselves as own resources for the EU budget? These were the central questions discussed at the FairTax conference "Options for an EU Tax as an EU Own Resource", at the Austrian Institute of Economic Research WIFO, Vienna, on September 19, 2016. The research conference was organised by WIFO, Mendel University in Brno and King's College London within the "FairTax" project (www. fair-tax.eu). FairTax is a cross-disciplinary research project funded 2014-2018 by the European Union's Horizon 2020 research and innovation programme (Grant Agreement No. FairTax 649439). FairTax aims to produce recommendations on how fair and sustainable taxation and social policy reforms can increase the economic stability of EU Member States. It is coordinated by Åsa Gunnarsson, Umeå University and involves 11 partner research institutions from 9 countries. Methods and theories are based in law, economics, accounting, ethnography, gender studies, economic history, business, and statistics. 
29 researchers from a number of EU Member States presented their ideas on reform needs and options for the EU system of own resources and their work on alternative funding options for the EU budget to an audience of more than hundred persons. The conference was rounded up by a policy panel, to create a link from research to policy-makers. The policy panel included Iveta Radičová, former Prime Minister of Slovakia, Hans Jörg Schelling, Federal Minister of Finance of Austria, and Heinz Zourek, former Director General of the European Commission's Directorate General on Taxes and Customers Union (DG TAXUD). Mario Monti, head of the High Level Group on Own Resources (HLGOR), sent a video message to underline the importance of a future-oriented discussion about alternative own resources for the EU budget.

This special issue of Empirica-Journal of European Economics contains a selection of papers from the conference. They were selected from a larger number of submissions following the usual refereeing process of the journal.

In his paper "Institutions and the route to reform of the European Union's budget revenue, 1970-2017" Giacomo Benedetto sets the stage for a discussion on the future of the EU system of own resources. Using process-tracing, this paper charts the history of the changes in the EU's revenue since 1970. One of the main messages of the paper-to be seen as lesson to be learned for future reforms in the EU system of own resources-is that previous historic achievements on own resources were based on package deals: suggesting inter alia that reforms in EU revenue will promise success in particular when combined with reforms in EU expenditures aiming at strengthening EU value added.

The following three papers analyse concrete options for tax-based own resources.

In their paper "Analysis and quantification of a new fiscally neutral European tax", Mikulas Luptacik and Peter Luptacik study a new European tax or excise which would be based on taxing end consumption according to how much $\mathrm{CO} 2$ is emitted during the production of particular commodities, irrespective of whether all or a part of this process takes place inside or outside the EU. The model calculations based on the Input-Output-Table for the EU-27 for the year 2011 yield a tax rate of 40.69 euros per tonne of $\mathrm{CO} 2$ emissions, which could have generated revenues of $1 \%$ of EU GDP. In line with the principle of fiscal neutrality, a reduction of labour taxes by $2.03 \%$ could compensate the introduction of the $\mathrm{CO} 2$ tax. The cost push effects lead to change of relative prices in favour of environmentally produced goods and services.

A carbon-based flight ticket tax as sustainability-oriented tax-based resource is considered by Alexander Krenek and Margit Schratzenstaller. According to the analysis conducted in their paper "Sustainability-oriented tax-based own resources for the European Union: A European carbon-based flight ticket tax", assigning a carbon-based flight ticket tax to the EU level would reduce the tax enforcement problems inherent to mobile tax bases and put a stop to harmful tax competition between EU Member States. By replacing a part of national contributions to the EU budget a flight ticket tax can strengthen sustainability-orientation of the EU system of own resources. While revenues would be limited, at about $€ 3$ billion to $€ 5$ billion at tax rates between $€ 25$ and $€ 35$ per tonne carbon emissions, a carbonbased flight ticket tax may serve as an illustrative example to demonstrate the 
chances and challenges associated with international taxes in particular regarding their potential contribution to sustainable development.

The paper "Sustainability-oriented future EU funding: A financial transaction tax" by Veronika Solilová, Danuse Nerudová and Marian Dobranschi focuses on a financial transaction tax (FTT) as tax-based own resource. To estimate the revenue potential of an FTT, the authors designed a model based on a remittance system. They analyse full or partial replacement of VAT- and GNI-based own resources by the transfer of tax revenues from an FTT raised on the national level to the EU budget. FTT-based own resource would be able to fully replace the GNI-based own resource only for some EU Member States, while the VAT-based own resource can be fully replaced by a FTT-based own resource for the entire EU. Their results also show that from the EU11 (28) perspective, the tax is sufficient to fully replace VATor GNI-contributions if levied on the EU11 (28) level (not on the national level).

The conference, as well as the work done in the FairTax project on reform needs and options for the EU system of own resources, could hardly have been better timed and should provide valuable input for the ongoing discussion [see in particular the final report by the HLGOR (2016) or the European Commission's recently published "Reflection paper on the future of EU finances" (European Commission 2017)] on the EU level on the post-2020 EU budget. The discussions at the conference also made clear that there are a number of further interesting research questions and areas where further research seems necessary: for example concerning the regional incidence of tax-based own resources or their legal and institutional implementation.

\section{References}

Begg I (2011) An EU tax: overdue reform or federalist fantasy? Friedrich-Ebert-Stiftung, Berlin, International Policy Analysis. http://ec.europa.eu/budget/mff/hlgor/library/selected-readings/08DOC-COMM-AnEUTax-Begg-Feb2011.pdf

European Commission (2011) Financing the EU budget: report on the operation of the own resources system. Accompanying the document proposal for a council decision on the system of own resources of the European Union, Commission Staff Working Paper SEC (2011) 876 final/2. http:// ec.europa.eu/budget/library/biblio/documents/fin_fwk1420/proposal_council_own_resources_ annex_en.pdf

European Commission (2017) Reflection paper on the future of EU finances, Brussels. https://ec.europa. eu/commission/sites/beta-political/files/reflection-paper-eu-finances_en.pdf

European Parliament (2017) Working document on reform of the European Union's system of own resources, Brussels

Ferrer JN (2008) Can reforming own resources foster policy quality? Sieps. http://sieps.hemsida.eu/sites/ default/files/68-20083.pdf

Fuest C, Heinemann F, Ungerer M (2015) Reforming the financing of the European Union: a proposal. Intereconomics 50(5):288-293

Haug J, Lamassoure A, Verhofstadt G, Gros D, Ricard-Nihoul G, De Grauwe P, Rubio E (2011) Europe for growth: for a radical change in financing the EU. https://papers.ssrn.com/sol3/papers. cfm?abstract_id=1898678

High Level Group on Own Resources-HLGOR (2016) Future financing of the EU, High Level Group on Own Resources, Brussels. http://ec.europa.eu/budget/mff/hlgor/library/reports-communication/ hlgor-report_20170104.pdf 
Iozzo A, Micossi S, Salvemini M (2008) A new budget for the European Union?. https://papers.ssrn.com/ sol3/papers.cfm?abstract_id=1334050

Lipatov V, Weichenrieder A (2016) The subsidiarity principle as a guideline for financing the European budget. In: Büttner T, Thöne M (eds) The future of EU finances. Mohr Siebeck, Tübingen, pp 15-29

Richter S (2008) Facing the monster 'Juste retour': on the net financial position of member states vis-à-vis the EU budget and a proposal for reform. The Vienna Institute for International Economic Studies, wiiw, Research Report No. 348

Schratzenstaller M (2013) The EU own resources system - reform needs and options. Intereconomics 48(5):303-313

Schratzenstaller M, Krenek A, Nerudová D, Dobranschi M (2016) EU taxes as genuine own resources to finance the EU budget: Pros, cons and sustainability-oriented criteria to identify potential tax candidates, FairTax Working Paper No. 3. http://umu.divaportal.org/smash/get/diva2:934128/ FULLTEXT01.pdf. Accessed 16 Oct 2017

Schratzenstaller M, Krenek A, Nerudová D, Dobranschi M (2017) EU taxes for the EU budget in the light of sustainability orientation—a survey. Jahrbücher für Nationalökonomie und Statistik, aop. doi:10. 1515/jbnst-2017-1106 